\title{
Ignored and invisible: internally displaced persons (IDPs) in the face of COVID-19 pandemic
}

\author{
Dan Jezreel A. Orendain ${ }^{1} \cdot$ Riyanti Djalante ${ }^{1}$ (D)
}

Received: 7 May 2020 / Accepted: 30 July 2020 / Published online: 6 August 2020

(c) Springer Japan KK, part of Springer Nature 2020

\begin{abstract}
COVID-19 is impacting the whole world. The impacts are different on different countries and societal groups, and those who are poor, mobile, and displaced are disproportionally affected. There are different ways that they are affected: they are more vulnerable to contracting the disease while living in shelter, have many barriers to access to social services and health care, difficulty in accessing relief and aid, prone to livelihood loss, and financial insecurity.
\end{abstract}

Keywords COVID-19 $\cdot$ Internally displaced persons (IDPs) $\cdot$ Durable solutions $\cdot$ Vulnerable people

\section{Overview of internally displaced persons (IDPs)}

Imagine losing everything in a disaster or conflict-your home, your valuable possessions, even a person you hold dear. Imagine watching everything you have done to create a comfortable life crumble to the ground. Imagine being forced to move out of your home to another place with barely anything to your name, trying to cope from the shock. Imagine not knowing what to do, where to go, and who to lean on. This is what happens to an internally displaced person (IDP). They are "persons or groups of persons who have been forced or obliged to flee or to leave their homes [emphasis mine]". The causes may include armed conflict, violence, human rights violations, or even natural and manmade disasters. In contrast to a refugee that moves to another country, IDPs do not cross their country's border (United Nations General Assembly 1998, p. 3).

Internal displacement is considered as one of the most adversely impactful human mobility issues and urban

Handled by Michael O’Rourke, Michigan State University Philosophy, United States.

Riyanti Djalante

djalante@unu.edu

Dan Jezreel A. Orendain

orendain@student.unu.edu; nyadangarkista2003@gmail.com

1 United Nations University-Institute for the Advanced Study of Sustainability (UNU-IAS), Tokyo, Japan phenomena, both to the affected people and the city, and yet it remains underrepresented in all forms of narrativefrom international discourse, advocacy, research (UNOCHA 2018), and even within the sustainable development goals (Zeender 2018). We do not fully understand IDPs because of the lack of extensive systemic investigation of this extremely vulnerable group. There is a failure in properly helping and supporting them as most national and local policies do not reflect international guidelines on internal displacement (IDMC 2018, 2019). They remain ignored, invisible, and excluded (IFRC 2018).

Internal displacement is a cause for concern as the number of internally displaced persons annually is astounding. In 2017, 30.6 million people were forced out of their homes due to conflict and disasters (IDMC 2018). This slightly fell to 27.8 million in 2018 with $54.3 \%$ of total disaster displacement coming from the East Asia and Pacific while 69.1\% of conflict displacement came from Sub-Saharan Africa (IDMC 2019). Unfortunately, 2019 saw a huge spike in new displacements at 33.4 million, noted as the highest in 12 years. The long-standing conflict and violence in Syria, the Democratic Republic of the Congo (DRC), and Ethiopia led to approximately 4.57 million new conflict displacements. Cyclones Fani and Bulbul resulted to 5 million new disaster displacements in India and Bangladesh alone. More alarming is that 2019 holds the highest ever recorded total of conflict displacement at 45.7 million people and a first time estimate of 5.1 million total disaster displacements leading to a final tally of 50.8 million IDPs (IDMC 2020). 
There are numerous calls, humanitarian guidelines, and various global to regional compacts addressing this issue. Yet, there are no lasting and durable solutions for IDPs, and they continue to be extremely vulnerable and are constantly exposed to various risks especially within the urban frame.

\section{In a pandemic that is challenging urban systems and infrastructure, what happens to the internally displaced?}

The coronavirus disease (COVID-19 Pandemic) emerged in Wuhan, China and was announced as a global pandemic by the World Health Organisation (WHO) on March 11, 2020. The impacts are global and as of 14 July 2020, there have been 13,240,715 cases, with 575,601 deaths, and 7,707,191 recoveries (Worldometer 2020). As the world has literally been brought to a standstill due to COVID-19, vulnerable groups like urban IDPs are weakened and more prone to experiencing injustice and inequalities. They often have limited or even non-existent access to basic services, excluding them from most forms of aid and assistance. The internally displaced are unfortunately being left behind. There are five key points to make about the potential impacts of the COVID-19 pandemic on IDPs as countries and local governments continue to ignore their plight.

Unlike a regular member of a host community, IDPs are generally more vulnerable to contracting diseases, like COVID-19, because of where they initially find shelter in a host community. As they step into a new city, they usually have no access to safe housing, which is worsened by the lack of proper support and helpful information on what to do. These families, like most urban migrants, inevitably will find shelter in informal settlements. Informal settlements are often associated with many social problems (Nassar and Elsayed 2018) and are often seen as an urban nuisance (Marshall and Dolley 2019). These tightly packed and dense communities lack the necessary support systems to promote a secure and healthy life (McAdam et al. 2016; Dodman et al. 2017; Dissanayake et al. 2018). With social distancing and quarantine as the common strategies in slowing the spread of the virus, it is virtually impossible in tight, cramped, and usually unsanitary conditions of most informal settlements. Outside of informal settlements, some families find refuge in danger zones. In an interview last October 2019 with an IDP family displaced by Typhoon Haiyan, they had to craft a shanty on a sidewalk using found materials after they arrived in the host city. This is not a safe space in this COVID-19 pandemic or in any other health emergency.

Internally displaced persons often encounter systemic and structural obstacles in obtaining proper social services and health care (Fielden 2008). If there is a full-blown infection in a city, IDPs may not have access to proper information, especially if the local government fails to properly communicate and does not utilize a wide range of media platforms. They might not even be aware of the pandemic and the lockdown. The economic divide between those who can afford effective health care and those who cannot, like IDP families, should also be considered. Most IDPs may not have the financial capacity or even the ability to access social and health services (Chu and Michael 2018; Nassar and Elsayed 2018). Even if they do have access to free health care, they might compete with others, especially the host community, leading to social tensions and weakened social networks (Sridarran et al. 2018). Most hospitals also have limited capacity, manpower, and resources. Reports show how COVID-19 has put extreme pressure and revealed gaps health systems globally (Lacina 2020). Most of these IDPs also deal with trauma and other psychosocial issues from the previous crises (UNOCHA 2020). The same family mentioned in the first point shared that Typhoon Haiyan extremely traumatized their son and that he requires constant monitoring and care. To this day, the son undergoes therapy and maintains medication to cope with the psychological stress. The pressures of COVID-19 to health infrastructures potentially threatens his physical and mental health as he might not be prioritized and given immediate and proper care.

Internally displaced persons may encounter obstacles in obtaining relief and aid in a lockdown due to citizenship issues. There are cases when an IDP lose their identity documents and are not registered in the host community (IFRC 2018; UNOCHA 2020). Language barriers, cultural divide, Indigenous or ethnic discrimination, racism, and other forms of exclusion may also come into play. Citizenship rights often equal access to services and support systems of a government (Chu and Michael 2018). Without this "right", IDPs may find it difficult to receive any financial assistance, food pack, and any relief aid. Unless a free-for-all assistance is employed, like Ormoc City's (Philippines) food aid to all households without need of identification (Bañoc 2020), an IDP family's welfare is underserved.

With possible long-term effects, internally displaced families are extremely vulnerable to livelihood loss and financial insecurity compared to members of the host city or community (The World Bank 2019). Often facing economic marginalization and exploitation (Chu and Michael 2018), a handful of IDP families interviewed in Davao City relied on informal economies by becoming small-scale entrepreneurs. They sell food in offices, have a small sari-sari store, or take odd jobs here and there just to earn a living. A lockdown basically cuts off these sources of income, leading to financial decline that pushes them deeper into poverty and depravity. Even with a "heavy-handed approach" to the pandemic in the Philippines (Santos 2020), vulnerable Filipinos are violating lockdown protocols due to the lack of 
income and hunger further amplified by inadequate relief and aid of local government units (Talabong and Gavilan 2020). In Thailand, the suicide rate is rising because of the economic impacts of the lockdown (Thai PBS World 2020; Japan Times 2020). This financial insecurity, coupled with weak social support systems and infrastructures, may also lead to food insecurity, mental health decline, health issues that threatens their quality of life.

All these compounding issues and challenges lead to our final point. The reverberating negative effects of a pandemic may result in a secondary displacement or forced migration. Falling into extreme poverty, hunger and food insecurity, losing a job or source of income, a death in the family due to the virus, and other drivers can force IDP families to move again (Carrasco et al. 2016; Sovacool 2018). We have not even factored into the equation the vulnerability of these groups to climate change impacts, extreme weather events, sea level rise, new and emerging disasters, other drivers or stressors, and other forms of unrest and violence. The moment IDPs are forced out, any progress and development they have barely scraped together will be in vain.

\section{Toward lasting and durable solutions for IDPs}

The COVID-19 pandemic reevaluates current understanding of internal displacement. It begins with the right data and information on the status, conditions, and experiences of IDPs. Previous health emergencies like the 2003 SARS epidemic and the 2014-2016 Ebola outbreak in West Africa failed to consider internal displacement. Fortunately, the 2019 Ebola outbreak in DRC and conflict displacement was carefully monitored. The International Organization for Migration mentioned IDPs facing increasing risks of exposure to the virus and other diseases, further amplified by the rising number of the displaced, thus the need for relocation and improved monitoring (IOM 2019). Likewise, the COVID-19 pandemic provides opportunities to closely examine the actual direct and reverberating impacts of an epidemic or pandemic on IDPs.

The UN cites "armed conflict, situations of generalized violence, violations of human rights or natural or humanmade disasters" as the causes of IDPs forced from their homes to another within an "internationally recognized state border" (UN 1998, p. 3). Is it time to expand and improve on this definition? Is an epidemic or a pandemic a new driver to displacement? Or has it always been an unseen or unrecognized variable? Beyond immediate responses to the growing social, economic, and physical insecurity globally, how do we address issues of the internally displaced in the face of an epidemic or pandemic as they are more likely being excluded from the general narrative?

The COVID-19 pandemic highlights various social, political, and international issues globally, within national borders, up to the smallest community. There are successes and there are painful failures in the responses to the pandemic. Internally displaced persons and families have yet to be given proper attention and sufficient care. The more we fail to provide for the needs of vulnerable groups, the more we erode their resilience, which undermines the sustainability and inclusivity of our cities and communities. There is a need to address internal displacement as it often a tenuous and less protected status than refugees since they must rely on the authorities that may be the cause of their flight (Parish 2015). We must bear in mind that everyone-from the international community, to national governments and their local counterparts, and various other actors and stakeholders-must undertake integrated, long-term and durable solutions and should never ignore or leave anyone behind (UN 2015; The World Bank 2018).

\section{References}

Bañoc RF (2020) Opinion: Mayor Richard Gomez initiative vis-à-vis COVID-19. Cebu Daily News-Philippine Daily Inquirer. https ://cebudailynews.inquirer.net/304967/mayor-richard-gomez-initi ative-vis-a-vis-covid-19. Accessed 30 July

Carrasco S, Ochiai C, Okazaki K (2016) Disaster induced resettlement: multi-stakeholder interactions and decision making following tropical storm Washi in Cagayan de Oro, Philippines. Procedia Soc Behav Sci 218:35-49. https://doi.org/10.1016/j.sbspr o.2016.04.008

Chu E, Michael K (2018) Recognition in urban climate justice: marginality and exclusion of migrantsin Indian cities. Environ Urban 31(1):139-156. https://doi.org/10.1177/0956247818814449

Dissanayake P, Hettiaarachchi S, Siriwardana C (2018) Increase in disaster risk due to inefficient environmental management, land use policies and relocation policies. Case studies from Sri Lanka. Procedia Eng 212:1326-1333. https://doi.org/10.1016/j.proen g.2018.01.171

Dodman D, Leck H, Rusca M, Colenbrader S (2017) African urbanisation and urbanism: implications for risk accumulation and reduction. Int J Disaster Risk Reduct 26:7-15. https://doi.org/10.1016/j. ijdrr.2017.06.029

Fielden A (2008) Ignored displaced persons: the plight of IDP's in urban areas. New Issues in Refugee Research: Research Paper No. 161. UNHCR Policy Development and Evaluation Service

IFRC (2018) World Disasters Report 2018 leaving no one behind, executive summary - the international humanitarian sector must do more to respond to the needs of the world's most vulnerable people. IFRC, Geneva, p 16

Internal Displacement Monitoring Centre (2018) Global report on internal displacement 2018. Internal Displacement Monitoring Centre, Geneva, p 120

Internal Displacement Monitoring Centre (2019) Global report on internal displacement 2018. Internal Displacement Monitoring Centre, Geneva, p 120

Internal Displacement Monitoring Centre (IDMC) (2020) Global report on internal displacement. Norwegian Refugee Council, Geneva, p 136

International Organization for Migration (2019) New Spike in Displacement in Eastern DRC Further Complicated Ebola Response, Requires Urgent Relocation and Response. https://www.iom.int/ 
news/new-spike-displacement-eastern-drc-further-complicate s-ebola-response-requires-urgent. Accessed 30 July

Japan Times (2020) Public suicide attempt highlights plight of millions of Thais waiting for virus aid. https://www.japantimes.co. jp/news/2020/04/29/asia-pacific/social-issues-asia-pacific/publi c-suicide-attempt-thailand-coronavirus-aid/\#.XrOfTc7iuUk. Accessed 30 July

Lacina L (2020) COVID-19 reveals gaps in health systems: WHO Briefing. World Economic Forum. https://www.weforum.org/ agenda/2020/05/covid-19-reveals-gaps-in-public-health-syste m-who-briefing/. Accessed 30 July

Marshall F, Dolley J (2019) Transformative innovation in peri-urban Asia. Res Policy 48:983-992. https://doi.org/10.1016/j.respo 1.2018.10.007

McAdam J, Kalin W, Weerasinghe S (2016) International law and sealevel rise: forced migration and human rights. Fridtjof Nansen Institute, Lysaker

Nassar D, Elsayed H (2018) From informal settlements to sustainable communities. Alex Eng J 57:2367-2376. https://doi.org/10.1016/j. aej.2017.09.004

Parish E (2015) The Bittersweet coast: environments of war and aftermath in Colombia. Dissertation

Santos AP (2020) Poverty punished as Philippines gets tough in virus pandemic. Al Jazeera. https://www.aljazeera.com/news/2020/04/ poverty-punished-philippines-tough-virus-pandemic-2004130639 21536.html. Accessed 30 July

Sovacool BK (2018) Bamboo beating bandits: conflict, inequality, and vulnerability in the political ecology of climate change adaptation in Bangladesh. World Dev 102:183-194. https://doi.org/10.1016/j. worlddev.2017.10.014

Sridarran P, Keraminiyage K, Amaratunga D (2018) Enablers and barriers of adapting post-disaster resettlements. Procedia Eng 212:125-132. https://doi.org/10.1016/j.proeng.2018.01.017

Talabong R, Gavilan J (2020) 'Walang-wala na' Poor Filipinos fear death from hunger more than coronavirus. Rappler. https://www. rappler.com/newsbreak/in-depth/256695-poor-filipinos-fear-death -from-hunger-more-than-coronavirus. Accessed 30 July

Thai PBS World (2020) Report says Thailand's suicide rate increasing during coronavirus pandemic. https://www.thaipbsworld.com/ report-says-thailands-suicide-rate-increasing-during-coronaviru s-pandemic/. Accessed 30 July

The World Bank (2018) World Bank Report: forced displacement to cities demands an urban development approach to the crisis. https ://www.worldbank.org/en/news/press-release/2018/02/10/world -bank-report-forced-displacement-to-cities-demands-an-urban -development-approach-to-the-crisis. Accessed 30 July

The World Bank (2019) Informing durable solutions for internal displacement. https://www.worldbank.org/en/topic/poverty/publi cation/informing-durable-solutions-for-internal-displacement. Accessed 30 July

United Nations (2015) Transforming Our World: The 2030 Agenda for Sustainable Development A/Res/70/1

United Nations General Assembly (1998) Guiding Principles on Internal Displacement, UN Doc E/CN. 4/1998/53/Add. 2

UNOCHA (2018) Staying the course: delivering on the ambition of the World Humanitarian Summit, Agenda for Humanity Annual Synthesis Report 2018. In: Ridsdel B, Barajas L, Benedek C, Gupta $\mathrm{R}$, Easton M, McDevitt D (eds)

UNOCHA (2020) Global Humanitarian Overview 2020. UNOCHA, Geneva, $\mathrm{p} 88$

Worldometer (2020) https://www.worldometers.info/coronavirus/. Accessed 14 July 2020

Zeender G (2018) The sustainable development goals and IDPs. Forced Migr Rev 59(GP20):24-26

Publisher's Note Springer Nature remains neutral with regard to jurisdictional claims in published maps and institutional affiliations. 